\title{
Correction to: Relationship between sand dew and plant leaf dew and its significance in irrigation water supplementation in Guanzhong Basin, China
}

\author{
Zhifeng Jia ${ }^{1,2,3} \cdot$ Yandong $\mathrm{Ma}^{2,3}$ (I) $\cdot$ Peng $\mathrm{Liu}^{2} \cdot$ Congcong $\mathrm{Yao}^{2}$
}

Published online: 3 November 2019

๑) Springer-Verlag GmbH Germany, part of Springer Nature 2019

\section{Correction to: Environmental Earth Sciences (2019) 78:354 https://doi.org/10.1007/s12665-019-8345-6}

Unfortunately the online version of the original article contains several citations of Jannis et al. 2018, where the first and last name was accidently mix up. The correct citation should be Groh et al. 2018 and the corresponding reference list should contain the information:

Groh J, Slawitsch V, Herndl M, Graf A, Vereecken H, Pütz $\mathrm{T}$ (2018) Determining dew and hoar frost formation for a low mountain range and alpine grassland site by weighable lysimeter. J Hydrol 563:372-381. https://doi.org/10.1016/j. jhydrol.2018.06.009

instead of:

Jannis G, Veronika S, Markus H, Alexander G, Harry V, Thomas P (2018) Determining dew and hoar frost formation for a low mountain range and alpine grassland site by weighable lysimeter. J Hydrol 563:372-381. https://doi. org/10.1016/j.jhydrol.2018.06.009

The original article can be found online at https://doi.org/10.1007/ s12665-019-8345-6.

Yandong Ma

mayandongemail@163.com

1 Research Institute of Water and Development, Chang'an University, No. 126 Yanta Road, Xi' an 710054, Shaanxi, China

2 School of Environmental Science and Engineering, Chang'an University, No. 126 Yanta Road, Xi' an 710054, Shaanxi, China

3 Key Laboratory of Subsurface Hydrology and Ecological Effects in Arid Region of the Ministry of Education, Chang' an University, No. 126 Yanta Road, Xi' an 710054, Shaanxi, China
Publisher's Note Springer Nature remains neutral with regard to jurisdictional claims in published maps and institutional affiliations. 